\title{
O FILÓSOFO EXPERIMENTADOR
}

\author{
Kellison Lima Cavalcante ${ }^{1}$
}

A essência e a existência, ora tessituras de um filósofo contemplador,

fulguraram em sua real potência

enunciando a razão de um sábio admirador.

Contudo, em sua singularidade, o filósofo desvela-se um experimentador perquirindo um ideal de racionalidade na ética do devir de um provocador.

Em sua tenra sensibilidade ressoa o firmamento de uma investigação criadora mergulhada na personificação da novidade, transcendendo sua concepção problematizadora.

O filósofo é agora um criador de conceitos como em uma constelação de acontecimentos semeados no horizonte dos feitos em um solo múltiplo de pensamentos.

$$
\begin{gathered}
\text { Nesse por vir } \\
\text { de um plano de imanência, } \\
\text { o construir } \\
\text { é dar consistência. }
\end{gathered}
$$

Infimamente, esse experimentador nada perde do infinito do seu horizonte contemplador pois percorre o mundo irrestrito.

$$
\begin{gathered}
\text { Permite-se conhecer o insólito, } \\
\text { fazendo e desfazendo, } \\
\text { em um ciclo sólito } \\
\text { de um caminho estupendo. }
\end{gathered}
$$

O conceito e criação articulam-se em novos encontros e novas possibilidades de experimentação erigidos, ao mesmo tempo, em seus reecontros.

1 Licenciado em Filosofia (UFPI), Especialista em Filosofia Contemporânea (Faculdade Souza), Mestre em Tecnologia Ambiental (ITEP). E-mail: kellisoncavalcante@hotmail.com. 